\title{
Perencanaan Jumlah Kebutuhan dan Posisi Lokasi Fasilitas Berbasiskan Otomata Selular
}

\author{
Made Irma Dwiputranti \\ Program Diploma D3 Logistik Bisnis Politeknik Pos Indonesia \\ email:madeirma80@gmail.com
}

\begin{abstract}
Abstrak
Fasilitas umum adalah sarana publik yang diperuntukan bagi masyarakat untuk menunjang kebutuhan sehari-hari antara lain, fasilitas pendidikan, kesehatan, perbelanjaan, niaga, dan lain-lain. Jumlah fasilitas tersebut harus disesuaikan dengan pertumbuhan jumlah penduduk sehingga tetap dapat memberikan kenyamanan. Penelitian ini mengembangkan dua buah model, model pertama adalah model prediksi jumlah pendaftar yang menggunakan model Miranda dan Monteiro (1999) dan sebaran pendaftar anak sekolah dasar dengan metode otomata selular. Model kedua yaitu model perencanaan kebutuhan lokasi fasilitas sekolah dasar yang menghasilkan suatu keputusan apakah sekolah yang ada perlu ditambah kapasitasnya (daya tampung) atau harus dibangun sekolah dasar yang baru. Hasil perhitungan diperoleh pada tahun 2023 dibangun satu buah sekolah dasar baru di Kelurahan Derwati dengan daya tampung 480 orang pendaftar per sekolah. Model dan mekanisme penentuan fasilitas kebutuhan sekolah ini diujicobakan pada dua skenario. Skenario pertama adalah jika daya tampung sekolah diperkecil dari 480 siswa pendaftar menjadi 360 siswa pendaftar. Sementara skenario kedua adalah menaikkan jumlah pendaftar menjadi 720 orang calon pendaftar persekolah. Hasilnya pada skenario pertama terjadi penambahan tiga buah fasilitas sekolah baru, yaitu sekolah baru SD ke-6 tahun 2020, SD ke-7 tahun 2022 dan SD Ke-8 tahun 2024 masing-masing di Kelurahan Derwati, Cipamokolan dan Mekarjaya. Sebaliknya apabila daya tampung sekolah diperbesar dari 480 orang.
\end{abstract}

Kata kunci : otomata selular,lokasi fasilitas.

\section{PENDAHULUAN}

Fasilitas umum adalah prasarana yang disediakan pemerintah bagi masyarakat dalam mempermudah melakukan sesuatu maupun dalam menunjang kebutuhan hidupnya. Menurut Permendagri Nomor 1 tahun fasilitas yang disediakan oleh pemerintah bagi masyarakat meliputi fasilitas pendidikan, kesehatan, perbelanjaan, niaga, pemerintahan, rekreasi, kebudayaan dan olah raga serta pemakaman umum. Keberhasilan suatu fasilitas umum di suatu wilayah, dapat dilihat dari minat dan kesediaan masyarakat untuk memanfaatkan fasilitas umum tersebut. Menurut Ballou (1999), perencanaan lokasi fasilitas umum yang akan ditetapkan harus sangat sensitif terhadap berbagai faktor diantaranya, lokasi penem patan, populasi, pola konsumen, infrastruktur, akses jalan, alat transportasi, jarak dan waktu tempuh menuju lokasi fasilitas umum.

Fasilitas umum dapat dimiliki oleh pemerintah atau pihak swasta tergantung dari sifat serta bentuk pelayanannya. Perbedaan kepemilikan tersebut terletak pada tujuan dari pendirian lokasi fasilitas umum yang dimaksud. Pada perusahaan swasta, keuntungan (profit) menjadi faktor utama, namun

https://ejurnal.poltekpos.ac.id/index.php/logistik/index fasilitas umum yang didirikan oleh pemerintah bersifat sosial dan sangat memperhatikan wilayah, populasi penduduk, kemudahan dan waktu tempuh serta dapat menjangkau seluruh lapisan masyarakat (Segura, 2005).

Kecamatan Rancasari merupakan wilayah Kotamadya Bandung, pelaksanaannya terhitung tanggal 1 April 1989. Kecamatan Rancasari mempunyai luas wilayah 1.503.162 Ha, terdiri atas 4 kelurahan, yaitu Kelurahan Manjahlega, Kelurahan Mekarjaya, Kelurahan Cipamakolan dan Kelurahan Derwati. Empat kelurahan tersebut terdiri atas 48 rukun warga (RW) dan 316 rukun tetangga (RT) (Kecamatan Rancasari,2020). Berdasarkan data tahun 2017 jumlah penduduk di Kecamatan Rancasari pada Kelurahan Manjahlega sebanyak 17.233 jiwa, pada Kelurahan Cipamokolan sebanyak 20.900 jiwa, pada Kelurahan Mekarjaya sebanyak 17.095 jiwa dan pada Kelurahan Derwati sebanyak 16.557 jiwa dengan total jumlah penduduk di Kecamatan Rancasari sebanyak 71.785 jiwa. Dari data Kecamatan Rancasari diketahui bahwa terdapat lima buah lokasi sekolah dasar negeri. Berdasarkan data pertumbuhan penduduk yang tinggi tersebut, maka Kecamatan Rancasari memerlukan pemenuhan kebutuhan

Page 42 
fasilitas umum khususnya sekolah dasar. Hal ini dikarenakan minimnya fasilitas umum berupa sekolah dasar negeri.Berdasarkan data di atas jumlah penduduk yang terpadat adalah di Kelurahan Cipamokolan, sementara sarana sekolah dasar yang tersedia hanya satu buah. Sementara di Kelurahan Mekarjaya terdapat dua buah sekolah dasar sedangkan di kelurahan lainnya masing-masing memiliki satu buah sekolah dasar. Penempatan lokasi fasilitas sekolah dasar tersebut bertentangan dengan Peraturan Mendiknas No 24 tahun 2007, yang menyatakan bahwa setiap satu SD/MI dengan jumlah penduduk maksimum 2000 jiwa harus dilakukan pembangunan SD/MI baru. Maka satu desa/kelurahan harus dapat dilayani oleh minimum satu SD/MI.

Penelitian ini bertujuan untuk membangun suatu model keputusan pembangunan sekolah dasar baru di Kecamatan Rancasari. Pengembangan model terdiri atas dua tahap yaitu tahap pertama dengan memprediksi jumlah pendaftar yang mengadopsi model Miranda dan Monteiro (1999), model tersebut menggunakan metode otomata selular dengan konsep pertetanggaan Moore di mana sebuah sel dipengaruhi oleh delapan buah sel tetangga yang terdekat, kemudian pendaftar tersebut akan disebarkan ke dalam bentuk sel. Tahap kedua adalah dengan membangun model penentuan keputusan pembangunan lokasi fasilitas sekolah dasar yang menghasilkan suatu keputusan apakah sekolah yang ada perlu ditambah kapasitasnya (daya tampung) atau harus dibangun sekolah dasar yang baru. Jika keputusannya dibangun sekolah baru maka akan ditentukan dimana dan kapan sekolah dasar tersebut harus dibangun dengan menggunakan optimisasi pencarian posisi lokasi baru dan penentuan waktu pembangunan lokasi fasilitas sekolah. Pencarian lokasi tersebut dilakukan dengan mempertimbangkan daerah jangkauan (coverage area) pendaftar, jumlah pendaftar untuk setiap sekolah, dan posisi lokasi fasilitas.

\section{Teori Lokasi ,Otomata Selular, Fasilitas Pendidikan Dasar dan Metode Chebyshev}

\section{Teori Lokasi}

Teori lokasi adalah ilmu yang menyelidiki tata ruang (spatial order) kegiatan ekonomi, atau ilmu yang menyelidiki alokasi geografis dari sumber-sumber yang potensial, serta hubungannya dengan atau pengaruhnya terhadap keberadaan berbagai macam usaha/kegiatan lain baik ekonomi maupun sosial

https://ejurnal.poltekpos.ac.id/index.php/logistik/index
(Tarigan, 2006). Menurut Tarigan, tingkat aksesibilitas dipengaruhi oleh jarak, kondisi prasarana perhubungan, ketersediaan berbagai sarana penghubung termasuk frekuensinya dan tingkat keamanan serta kenyamanan untuk melalui jalur tersebut. Dalam analisis kota yang telah ada atau rencana kota, dikenal standar lokasi (standard for location requirement) atau standar jarak (Jayadinata, 1999).

Otomata selular adalah model yang paling sederhana dari proses distribusi spasial, dimana otomata selular merupakan sebuah sistem berhingga dengan berbagai kisi yang mirip dengan papan catur dan tiap kisi diisi oleh bidak-bidak yang dinamis, dan dalam dinamikanya mematuhi aturan-aturan yang didefinisikan secara aljabar. Otomata selular terdiri dari suatu array sel, dimana masing-masing sel diijinkan untuk berada disalah satu dari beberapa keadaan (state). Otomata selular ditemukan pada tahun 1940 oleh ahli matematika John Von Neuman dan Stanislaw Ulam. Otomata selular yang paling terkenal adalah "Game of Life" yang ditemukan oleh ahli matematika John Conway pada tahun 1960. Otomata selular merupakan suatu sistem yang terdiri atas keadaan (state), dimana state menyatakan suatu informasi mengenai input data sebelumnya dan dapat pula dianggap sebagai memori ( Zito dan Spataro, 2006).

Aplikasi otomata berkembang pesat seiring dengan peningkatan kemampuan komponen elektronik dan struktur logika matematika. Tahun 30-an, Alan Turing mendesain secara teoritis sebuah mesin yang dapat memproses sejumlah persamaan tanpa pengarahan manusia. Mesin ini lalu dinamai dengan Mesin Turing. Turing menunjukkan bahwa mesin tersebut merupakan sebuah mesin komputasi universal. Mesin turing adalah basis awal dari perkembangan perangkat komputer digital yang ada saat ini.

Pada dekade 40-an dan 50-an, Warren McCulloch dan Walter Pitts membangun jaringan saraf artifisial (artifisial neural). Saraf artifisial ini menunjukkan bahwa kapasitas belajar dari pengalaman dapat terkomputasikan. Pada tahun 1956, Herbert Simon, nobelis ekonomi, dan pakar ilmu komputer Carnegie Mellon University, Allan Newell membangun sebuah program yang disebut logic theorist, yang mensimulasikan cara berfikir manusia dalam komputer. Simon dan Newell, lalu mengembangkan sebuah program baru yang disebut GPS (General Problem Solver). GPS cukup unik, karena memiliki tujuan dan komputer akan bekerja mencapai tujuan tersebut. Simon dan Newel menemukan bahwa GPS

Page $\mid 43$ 
dalam beberapa kasus sesuai dengan cara berfikir manusia.

Penelitian ini memicu kelahiran disiplin kecerdasan buatan (artificial intelegence), selanjutnya disebut AI. AI pada mulanya adalah studi tentang sifat-sifat formal (mekanis atau komputasional) dari masalahmasalah dan metode-metode pemecahan masalah, dengan bantuan komputer yang dilengkapi kemampuan memecahkan masalah yang dapat dibandingkan dengan kemampuan manusia. Beberapa peneliti yang memberikan pengaruh besar dalam AI antara lain expert system, otomata selular dan artificial life.

\section{Otomata Selular}

Otomata selular adalah sistem spasial luas terdesentralisasi (decentralized spatially extended system), selanjutnya ditulis DSES adalah sebuah sistem yang memiliki elemen yang sangat banyak dan berada pada ruang spasial $n$-dimensi dan tidak memiliki sebuah elemen atau grup elemen tunggal yang mampu mempengaruhi seluruh sistem secara langsung (Hordijk, 1994).

Elemen-elemen didalam otomata selular memiliki hubungan lokal, sederhana dan identik. Otomata selular memiliki dua buah komponen antara lain (Mitchell, 1998):
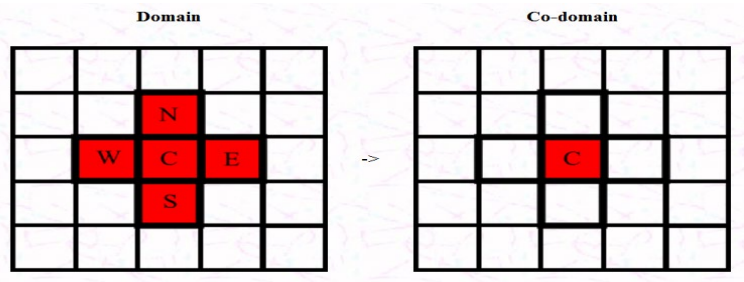

Gambar A: Sistem Pertetanggaan Newmann
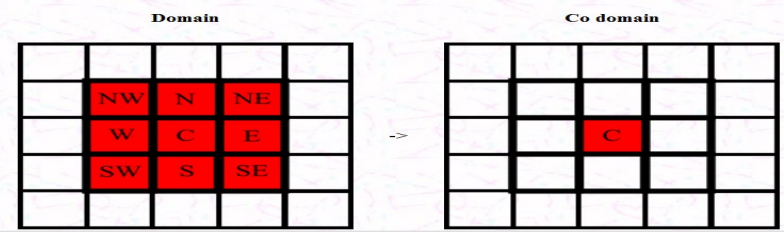

Gambar B: Sistem Pertetanggaan Moore

\section{Gambar 1. Gambar A Sistem Pertetanggaan Newmann dan Gambar B Sistem Pertetanggaan Moore}

Gambar 1.A merupakan sistem pertetanggaan Newmann dimana sebuah sel yang berada di titik pusat (center) terhubung dengan empat sel lain yang terletak dibagian north, east, south, dan west. Gambar B merupakan sistem pertetanggaan Moore dimana sebuah sel yang berada pada titik pusat https://ejurnal.poltekpos.ac.id/index.php/logistik/index (center) terhubung dengan delapan sel lain pada delapan penjuru mata angin yang terletak dibagian northwest, north, northeast, east,southeast, south, southwest, west dan northwest. Ciri utama otomata dalam kelas ini adalah keterhubungan lokal antar sel homogen.

Page | 44 
Otomata selular tidak dapat dilepas dari Von Newmann. Von Newmann membangun sebuah otomata dengan sistem empat pertetanggaan (selanjutnya sistem ini disebut sistem pertetanggaan Von Newmann), (Mitchell, 1998).Von Newmann adalah yang pertama kali mendesain otomata selular yang sesuai dengan prinsip komputasi universal. Semenjak itu, otomata selular mulai digunakan sebagai alat permodelan.

\section{Fasilitas Pendidikan Dasar}

Pengadaan dan pendayagunaan sumber daya pendidikan dilakukan oleh pemerintah, masyarakat dan atau keluarga peserta didik. Pembakuan tipe sekolah dasar sangat diperlukan untuk mengetahui seberapa besar daya tampung suatu sekolah agar tidak terjadi penumpukan siswa yang menyebabkan ketidaknyamanan dalam proses belajar mengajar. Berdasarkan lampiran Keputusan Menteri Pendidikan Nasional No. 0424/U/1993 tanggal 1 Desember 1993, terdapat pembakuan tipe sekolah pada satuan pendidikan dasar, dengan perincian sebagai berikut.

Tabel 1. Pembakuan Tipe Sekolah Dasar

\begin{tabular}{|l|l|l|l|}
\hline \multirow{2}{*}{ No } & \multirow{2}{*}{ Kebutuhan } & \multicolumn{2}{|l|}{ Sekolah Dasar } \\
\cline { 3 - 4 } & & Tipe A & Tipe B \\
\hline 1. & Rombongan Belajar & 12 kelompok & 6 kelompok \\
\hline 2. & Peserta Didik & 480 siswa & 240 siswa \\
\hline
\end{tabular}

Tabel 1 di atas merupakan pembakuan tipe sekolah dasar berdasarkan tipe A dan tipe B. Sekolah tipe A terdiri atas 12 kelompok rombongan belajar dengan jumlah peserta didik adalah sebanyak 480 siswa. Sekolah tipe B terdiri atas 6 kelompok rombongan belajar dengan jumlah peserta didik adalah 240 siswa.

\section{Metode Chebyshev}

Metode untuk mengukur jarak dari satu lokasi ke lokasi lain salah satunya adalah dengan menggunakan metode Chebyshev. Metode Chebyshev adalah jarak antara dua vektor atau titik $p$ dan $q$, dengan standar koordinat $p i$ dan $q i$, masing-masing, yang dapat dirumuskan sebagai berikut (Cyrus, 2000):

$D_{\text {Chebyshev }}(\mathrm{p}, \mathrm{q})=\max _{\mathrm{i}}\left(\left|\mathrm{p}_{\mathrm{i}}-\mathrm{q}_{\mathrm{i}}\right|\right)$
Metode ini dikenal sebagai jarak papan catur, karena dalam permainan catur jumlah minimum untuk bergerak yang dibutuhkan oleh raja untuk pergi dari satu persegi pada papan catur sama dengan jarak chebyshev antara pusat kuadrat. Jika kotak memiliki panjang sisi satu, seperti yang direpresentasikan dalam ruang 2-D. Dalam dua dimensi jika titik $p$ dan $q$ memiliki koordinat

Cartesian $\left(x_{1}, y_{1}\right)$ dan $\left(x_{2}, y_{2}\right)$, mereka jarak Chebyshev adalah:

$$
\mathrm{D}_{\text {Chebyshev }}=\max \left(\left|\mathrm{x}_{2}-\mathrm{x}_{1}\right|,\left|\mathrm{y}_{1}-\mathrm{y}_{2}\right|\right)
$$




\begin{tabular}{|lllllllllllll|}
\hline & $\mathrm{A}$ & $\mathrm{b}$ & $\mathrm{c}$ & $\mathrm{d}$ & $\mathrm{e}$ & $\mathrm{F}$ & $\mathrm{g}$ & \multicolumn{3}{l|}{$\mathrm{H}$} & \\
8 & 5 & 4 & 3 & 2 & 2 & 2 & 2 & 2 & 8 \\
7 & 5 & 4 & 3 & 2 & 1 & 1 & 1 & 2 & 7 \\
6 & 5 & 4 & 3 & 2 & 1 & 6 & 1 & 2 & 6 \\
5 & 5 & 4 & 3 & 2 & 1 & 1 & 1 & 2 & 5 \\
4 & 5 & 4 & 3 & 2 & 2 & 2 & 2 & 2 & 4 \\
3 & 5 & 4 & 3 & 3 & 3 & 3 & 3 & 3 & 3 \\
2 & 5 & 4 & 4 & 4 & 4 & 4 & 4 & 4 & 2 \\
1 & 5 & 5 & 5 & 5 & 5 & 5 & 5 & 5 & 1 \\
& A & b & c & D & e & F & g & h & & \\
\hline
\end{tabular}

\section{Gambar 2. Ilustrasi Papan Catur pada Metode Chebyshev} Sumber:Cyrus 2000

Gambar 2 merupakan ilustrasi papan catur dengan menggunakan metode Chebyshev. Jarak Chebyshev antara dua ruang dipapan catur memberikan jumlah minimum. Ruang pada papan catur untuk menggerakkan bidak raja diperlukan untuk dapat bergerak secara diagonal, sehingga raja dapat melompat untuk menutupi jarak sehingga untuk menggerakkan bidak raja tersebut haruslah dicari jarak yang paling maksimum.

\section{PENGEMBANGAN MODEL}

Penelitian ini menggunakan 2 (dua) buah model untuk memecahkan masalah perencanaan kebutuhan lokasi fasilitas sekolah dasar yaitu:

1. Model 1

Model 1 merupakan model prediksi jumlah pendaftar per sel yang mengadopsi model Miranda dan Monteiro (1999). Model tersebut menggunakan metode otomata selular dengan konsep pertetanggaan Moore dimana sebuah sel dipengaruhi oleh delapan buah sel tetangga yang terdekat. Model Miranda dan Monteiro (1999) digunakan untuk memprediksi jumlah pendaftar yang dipengaruhi oleh pertumbuhan sel internal, eksternal dan kondisi existing pendaftar.

2. Model 2

Model 2 merupakan model penentuan keputusan pembangunan lokasi fasilitas sekolah dasar yang akan menghasilkan suatu keputusan apakah sekolah dasar yang sudah ada perlu ditambah kapasitasnya (daya tampung) atau harus dibangun sekolah dasar yang baru. Jika keputusannya dibangun sekolah dasar yang baru maka akan https://ejurnal.poltekpos.ac.id/index.php/logistik/index ditentukan dimana dan kapan sekolah dasar tersebut harus dibangun, dengan menggunakan teknik optimisasi pencarian posisi lokasi baru dan penentuan waktu pembangunan lokasi fasilitas sekolah.

\subsection{MODEL 1}

Model 1 akan memprediksi jumlah pendaftar untuk 5 (lima) tahun yang akan datang yaitu tahun 2020-2024. Model untuk memprediksi jumlah pendaftar diselesaikan dengan mengadopsi model Miranda dan Monteiro (1999). Sebelum memprediksi jumlah pendaftar terlebih dahulu dilakukan peramalan terhadap pertumbuhan internal pendaftar dengan menggunakan metode regresi. Output dari model Miranda dan Monteiro (1999) digunakan untuk memprediksi jumlah pendaftar sekolah dasar per sel untuk 5 (lima) tahun yang akan datang yaitu tahun 2020-2024 yang dipengaruhi oleh pertumbuhan sel internal, eksternal dan kondisi existing pendaftar.

Notasi yang digunakan dalam model 1 yaitu model prediksi jumlah pendaftar sekolah dasar adalah sebagai berikut:

$\alpha=$ Pengaruh pertumbuhan internal pendaftar

$\beta=$ Pengaruh interaksi antar sel karena pengaruh external pendaftar

$\delta=$ Kondisi awal pendaftar yang tidak dipengaruhi oleh pengaruh pertumbuhan internal pendaftar dan eksternal pendaftar

$N=$ Neighbour (tetangga) dari sel

$P d_{C}=$ Jumlah pendaftar setiap sel

$P I_{C}=$ Pertumbuhan internal pendaftar setiap sel 
Otomata selular dalam model ini digunakan untuk menginteraksi sel, sistem keterhubungan dalam otomata selular disebut dengan sistem pertetanggaan dari suatu sel yang dinyatakan dengan $N$ (neighbour) pada persamaan 3.1. Sistem pertetanggaan dua dimensi yang digunakan adalah sistem pertetanggaan Moore, dimana interaksi sebuah sel dipengaruhi oleh delapan buah sel tetangga yang terdekat. Jika tahun saat ini dinotasikan sebagai (t) maka jumlah pendaftar pada tahun berikutnya dinyatakan sebagai berikut:

$$
P d_{C}(t+1)=\alpha\left[P I_{C} P d_{C}(t)\right]+\beta \frac{1}{8} \sum_{N} P d_{C}(t)_{N}+
$$$$
\delta \text {....(3) }
$$

\subsection{MODEL 2 PENENTUAN KEPUTUSAN PEMBANGUNAN LOKASI FASILITAS SEKOLAH DASAR}

Model 2 merupakan model penentuan keputusan pembangunan lokasi fasilitas sekolah dasar yang akan menghasilkan suatu keputusan apakah sekolah dasar yang ada perlu ditambah kapasitasnya (daya tampung) atau harus dibangun sekolah dasar yang baru. Jika keputusan yang didapat adalah dengan membangun sekolah dasar baru maka langkah berikutnya adalah dengan menentukan waktu kapan dan dimana sekolah dasar tersebut harus dibangun.
Model penentuan keputusan pembangunan lokasi fasilitas sekolah dasar adalah suatu model pencarian posisi lokasi sekolah dasar pada suatu sel yang akan dibangun pada suatu posisi lokasi tertentu. Fungsi tujuan dari model adalah untuk minimisasi jangkauan pendaftar yaitu rentang pendaftar antar sekolah dasar yang paling minimum pada suatu sel. Posisi lokasi sekolah dasar yang baru akan dibangun pada sel dengan rentang pendaftar yang paling minimum, sehingga pemerataan pendaftar ketika didirikan sekolah dasar baru akan tercapai. Algoritma yang dikembangkan pada Model 2 terdiri dari Algoritma penentuan keputusan pembangunan lokasi fasilitas sekolah dasar dan tiga buah sub algoritma yaitu:

1. Sub-Algoritma penentuan coverage area tiap sekolah dasar (2a).

2. Sub-Algoritma penentuan jumlah pendaftar tiap sekolah dasar (2b).

a) Sub-Algoritma penentuan jumlah pendaftar maksimal (2b1)

b) Sub-Algoritma penentuan jumlah pendaftar minimal (2b2)

3. Sub-Algoritma penentuan posisi sekolah dasar baru (2c)

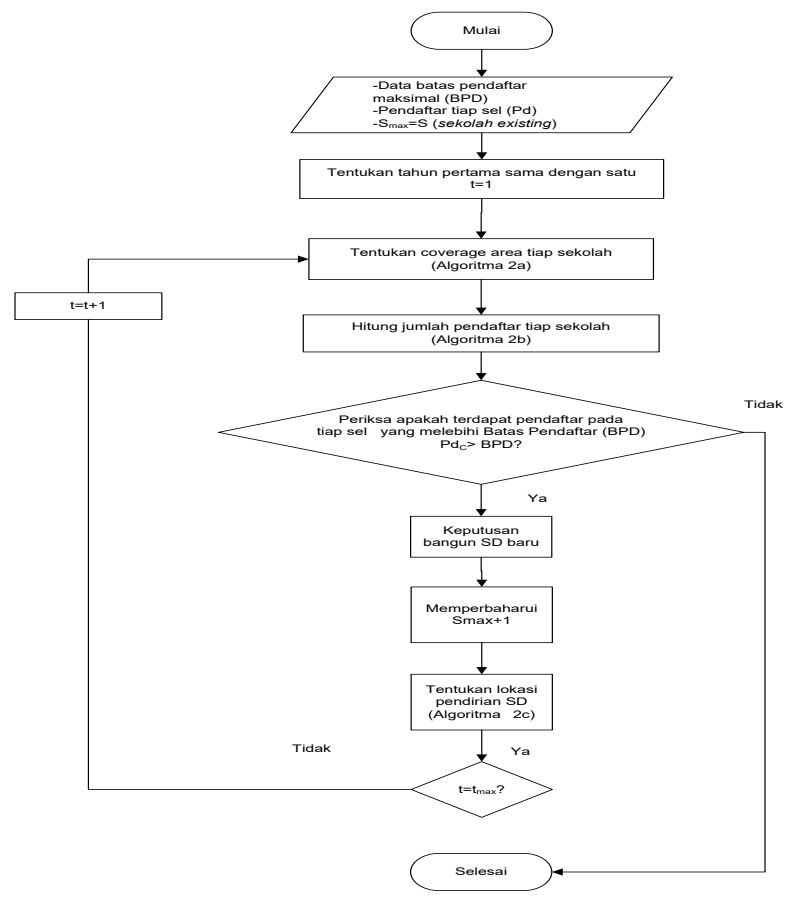

Gambar 3. Algoritma Penentuan Keputusan Pembangunan Lokasi Fasilitas Sekolah Dasar

\section{UJI COBA MODEL}

$\begin{array}{ll}\text { https://ejurnal.poltekpos.ac.id/index.php/logistik/index } & \text { Page | } 47\end{array}$ 
Untuk uji coba model, Kecamatan Rancasari di Bandung dipilih sebagai studi kasus. Kecamatan Rancasari terdiri atas 4 (empat) kelurahan yaitu Kelurahan Manjahlega, Kelurahan Mekarjaya, Kelurahan Cipamakolan dan Kelurahan /Derwati. Empat kelurahan tersebut terdiri atas 48 rukun warga (RW) dan 316 rukun tetangga (RT), (Kecamatan
Rancasari,2018). Kelurahan Manjahlega sebanyak 17.233 jiwa, pada Kelurahan Cipamokolan sebanyak 120.900 jiwa, pada Kelurahan Mekarjaya sebanyak 17.095 jiwa dan pada Kelurahan Derwati sebanyak 16.557 jiwa dengan total jumlah penduduk di Kecamatan Rancasari sebanyak 71.785 jiwa. Dari data Kecamatan Rancasari diketahui bahwa terdapat lima buah lokasi sekolah dasar negeri.

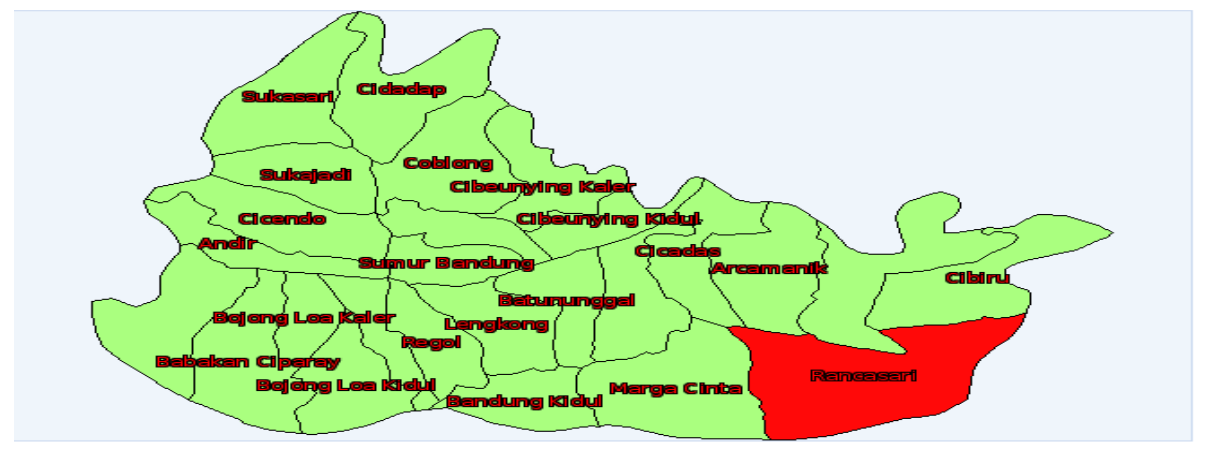

Gambar 4. Peta Kota Bandung

\section{ANALISIS}

Berdasarkan hasil perhitungan didapatkan nilai $\alpha, \beta$ dan $\delta$ pada Tabel 4.4 merupakan hasil prediksi dari model Miranda dan Monteiro (1999) yang akan digunakan untuk memprediksi jumlah pendaftar 5 (lima) tahun yang akan datang yaitu tahun 20202024, Sehingga Model peramalan untuk jumlah pendaftar di Kecamatan Rancasari adalah sebagai berikut:

$$
\begin{gathered}
P d_{C}(t+1)=11.3942\left[P I_{C} P d_{C}(t)\right]+ \\
0.053 \frac{1}{8} \sum_{N} P d_{C}(t)_{N}+0.688
\end{gathered}
$$

- $\mathrm{H}_{0}: \mu_{1}=\mu_{2}$, bahwa terdapat kesamaan pada jumlah pendaftar prediksi dengan jumlah data sebenarnya.

- $\mathrm{H}_{1}: \mu_{1} \neq \mu_{2}$, bahwa tidak terdapat kesamaan pada jumlah pendaftar prediksi dengan jumlah data sebenarnya.

Tabel 2. Hasil Uji t-test Paired

\begin{tabular}{|l|l|}
\hline Variabel & Nilai \\
\hline$\alpha$ & 11.3942 \\
\hline$\beta$ & 0.053 \\
\hline$\delta$ & 0.6887 \\
\hline
\end{tabular}

Pada Tabel 2 dengan tingkat kepercayaan 95\% diperoleh t-hitung sebesar 0,147. Dari hasil perhitungan daerah kritis $-0,2273<\mathrm{t}<0,2637$, maka $\mathrm{t}$ hitung berada diluar daerah kritis maka $\mathrm{H}_{0}$ diterima, maka model prediksi jumlah anak sekolah dasar dasar dinyatakan valid.

Proyeksi perencanaan lokasi fasilitas sekolah dasar sampai dengan lima tahun ke sepan (2020-2024) seperti ditunjukkan pada Gambar....Proyeksi ini didasarkan pada tingkat pertumbuhan penduduk terakhir dan selama horizon perencanaan diasumsikan tidak terjadi perubahan jalan raya.

Pencarian posisi lokasi baru pada sel $(\mathrm{x}, \mathrm{y})$ SD ke-6 dilakukan terhadap 110 buah titik posisi lokasi yang ada pada wilayah penelitian. Pencarian lokasi baru dilakukan dengan cara mencari jangkauan pendaftar SD yang paling minimum, artinya jika sekolah dasar dasar baru SD ke-6 didirikan di lokasi sel $(\mathrm{x}, \mathrm{y})$ maka jumlah pendaftar yang menumpuk pada suatu SD akan tersebar ke sekolah dasar baru. 


\begin{tabular}{|c|c|c|c|c|c|c|c|c|c|c|c|c|c|c|c|c|c|c|c|}
\hline 1 & 0 & 0 & 0 & 0 & 0 & 0 & 0 & 0 & 0 & 0 & 0 & 0 & 0 & 0 & 0 & 0 & 0 & & \\
\hline$z$ & 0 & 0 & 0 & 18 & 18 & 30 & 27 & 22 & 17 & 17 & 0 & 0 & 0 & 0 & 0 & 0 & 0 & & \\
\hline J & 0 & 0 & 0 & 10 & 10 & 26 & 39 & 31 & 11 & 8 & 0 & \begin{tabular}{l|l}
0 \\
\end{tabular} & 0 & 0 & 0 & 0 & 0 & & \\
\hline 4 & 0 & 0 & 0 & 5 & 9 & 8 & 10 & 53 & 62 & 11 & 0 & 0 & 0 & 0 & 0 & 0 & 0 & & \\
\hline 5 & 0 & 0 : & 12 & 8 & 11 & 8 & 10 & 39 & 41 & \begin{tabular}{|l|}
46 \\
\end{tabular} & 0 & 0 & 0 & 0 & 0 & 0 & 0 & & \multirow{11}{*}{$\begin{array}{l}\text { Cakupan SD Rancabolang } \\
\text { Cakupan SD Cipamokolan } \\
\text { Cakupan SD Derwati } \\
\text { Cakupan SD Cijawura } \\
\text { Cakupan SD Pasir Pogor } \\
\text { Cakupan SD Baru } \\
\text { Posisi Lokasi Sekolah } \\
\text { Lokasi pemukiman tercover ole } \\
\text { Lokasi Pemukiman tercover ole }\end{array}$} \\
\hline 6 & 0 & 0 & 6 & 11 & 4 & 6 & 12 & 11 & 30 & 21 & 21 & 0 & 0 & 0 & 0 & 0 & 0 & SD1 & \\
\hline 7 & 0 & 0 & 6 & 8 & 9 & 9 . & 12 & 9 & 9 & 9 & 121 & \begin{tabular}{l|l}
12 & 1 \\
\end{tabular} & 15 & 0 & 0 & 0 & $0 \mathrm{~s}$ & SD2 & \\
\hline 8 & 0 & 0 & 0 & 0 & 0 & 0 & 0 & 9 & 9 & 7 & 6 & $\begin{array}{l}411 \\
\end{array}$ & 15 & 10 & 0 & 0 & $0 \mathrm{~s}$ & SD 3 & \\
\hline 9 & 0 & 323 & 32 & 0 & 0 & 0 & 0 & 9 & 9 & 7 & 7 & \begin{tabular}{l|l}
4 & 1 \\
\end{tabular} & 11 & 10 & 10 & 0 & $0 \mathrm{~s}$ & SD 4 & \\
\hline 10 & 0 & 342 & 26 & 18 & 28 & 374 & 48 & 26 & 10 & 10 & 5 & 4 & 5 & 11 & 11 & 0 & $0 \mathrm{~s}$ & SD 5 & \\
\hline 11 & 0 & 702 & 25 & 17 & 27 & 37 & 49 & 65 & 8 & 4 & 5 & 4 & 5 & 5 & 11 & 0 & 05 & SD 6 & \\
\hline 12 & 0 & 913 & 32 & 21 & 36 & 375 & 50 & 84 & 9 & 5 & 10 & 5 & 5 & 9 & 11 & 0 & 0 & & \\
\hline 13 & 0 & 0 & 0 & 0 & 0 & 0 & 0 & 0 & 0 & 0 & 0 & 0 & 0 & 9 & 14 & 0 & 0 & & \\
\hline & 0 & 0 & 0 & 0 & 0 & 0 & 0 & 0 & 0 & 0 & 0 & 0 & 0 & 0 & 0 & \begin{tabular}{l|l} 
\\
\end{tabular} & 0 & & \\
\hline & 0 & 0 & 0 & 0 & 0 & 0 & 0 & 0 & 0 & 0 & 0 & 0 & 0 & 0 & 0 & 0 & & & \\
\hline & 1 & 2 & 3 & 4 & & & I & & & & & & & & & & & & \\
\hline
\end{tabular}

\section{Gambar 5. Prediksi jumlah pendaftar tahun 2020-2024}

Gambar 5 adalah visualisasi prediksi jumlah pendaftar tahun 2023-2024 dalam bentuk sel, dimana pada tahun 2023 merupakan waktu optimal pembangunan SD baru dimana terdapat satu buah sekolah baru yaitu SD ke-6 pada posisi $(9,12)$ dan sel yang berwarna pink muda menunjukkan cakupan wilayah sekolah baru SD ke-6, dimana pendirian sekolah baru tersebut akan merubah cakupan area pendaftar pada sekolah lainya. Prediksi pendaftar tahun 2024 menunjukkan perubahan pendaftar tahun 2023 ke tahun 2024. Berdasarkan hasil prediksi pendaftar dalam bentuk sel di atas, berdasarkan visualisasi tersebut kemudian dibuat rekapitulasi prediksi jumlah pendaftar sekolah dasar tahun 20202024 kedalam bentuk tabel yang dapat dilihat pada Tabel3.

Tabel 3. Rekapitulasi Prediksi Pendaftar SD tahun 2020-2024

\begin{tabular}{|c|c|c|c|c|c|}
\hline \multirow[t]{2}{*}{ Tahun } & \multicolumn{4}{|c|}{ Sekolah (orang) } & \\
\hline & SD 1 & SD 2 & SD 3 & SD 4 & SD 5 \\
\hline 2020 & 237 & 324 & 409 & 302 & 257 \\
\hline 2021 & 248 & 346 & 440 & 341 & 264 \\
\hline 2022 & 264 & 371 & 477 & 390 & 272 \\
\hline 2023 & 280 & 397 & 518 & 442 & 280 \\
\hline 2024 & 300 & 424 & 565 & 502 & 291 \\
\hline
\end{tabular}

$\begin{array}{ll}\text { SD 1 } & \text { SD Rancabolang } \\ \text { SD 2 } & \text { SD Rancaloa } \\ \text { SD 3 } & \text { SD Derwati } \\ \text { SD 4 } & \text { SD Cijawura } \\ \text { SD 5 } & \text { SD Pasir Pogor }\end{array}$

\subsection{Pencarian Lokasi Sekolah Dasar Baru}

Pencarian posisi lokasi baru pada sel $(\mathrm{x}, \mathrm{y})$ SD ke-6 dilakukan terhadap 110 buah titik posisi lokasi yang ada pada wilayah penelitian. Pencarian lokasi baru dilakukan dengan cara mencari jangkauan pendaftar
SD yang paling minimum, artinya jika sekolah dasar dasar baru SD ke-6 didirikan di lokasi sel $(\mathrm{x}, \mathrm{y})$ maka jumlah pendaftar yang menumpuk pada suatu SD akan tersebar ke sekolah dasar baru, maka jangkauan pendaftar yang paling minimum diperoleh posisi sel $(9,12)$. 
Tabel 4. Jangkauan Pendaftar Paling Minimum SD ke-6 Tahun 2023

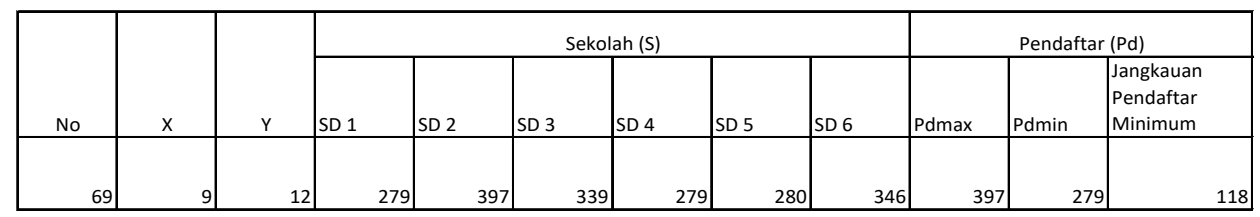

Tabel 4 menunjukkan jangkauan pendaftar paling minimum pada posisi sel $(9,12)$ di Kelurahan Derwati, bernilai paling minimum artinya apabila sekolah baru didirikan pada posisi lokasi sel $(9,12)$ maka jumlah pendaftar akan tersebar secara merata dibandingkan dengan jika posisi baru didirikan pada posisi lain.

\section{KESIMPULAN}

1. Penelitian ini mengembangkan penelitian terhadap fasilitas lokasi berbasiskan otomata selular.

2. Model Miranda dan Monteiro (1999) dapat digunakan untuk memprediksi jumlah pendaftar hal tersebut dapat dilihat dari hasil uji statistik $t$ test berpasangan yang menyatakan model valid.

3. Hasil yang diperoleh dari pengembangan model penentuan lokasi fasilitas sekolah adalah pada daya tampung 480 orang pendaftar terdapat sebuah sekolah baru di kelurahan Derwati pada tahun 2023 pada titik $(12,9)$.

\section{REFERENSI}

[1] Ballou, R. H. 1999. Business Logistic: Supply Chain Management. Fourth Edition. Pearson Prentice Hall, New Jersey.

[2] Chapin, Stuart.1965.Urban Land Use Planning: Second Edition, University of Illinois Press, Urbana.

[3] Cyrus,D.C.2000.Modern Mathematical Method for Physicist and Engineers.Cambridge University Press.ISBN 0521598273.

[4] Dieleman, F. M. et al. 2002. Urban Form And Travel Behaviour: Micro-Level Household Attributes and Residential Context, Urban Studies, Vol. 39, No.3, 507-527.

[5] Dahlan,R.M.2005. Perencanaan jaringan listrik dengan logika fuzzy dan otomata selular (studi kasus:Kecamatan Coblong Bandung). Tugas Akhir, Teknik Industri, Institut Teknologi Bandung, Bandung.

https://ejurnal.poltekpos.ac.id/index.php/logistik/index
[6] Dinas Pendikan kota Bandung 2018, Data Pertumbuhan Pendaftar Sekolah Dasar di Kecamatan Rancasari, data dikumpulkan berdasarkan survei yang dilakukan oleh penulis di lima sekolah dasar yang ada di kecamatan Rancasari.

[7] Daljoeni, N. 1992. Organisasi Keruangan dalam Teori dan Praktek.Bandung.Penerbit Alumni.

[8] Daniels,P.W.,A.M.Warnes,eds.1998. Movement in Cities:Spatial Perspectives on Urban Transport and Travel.London:Methuen \&Co.

[9] Daskin,M.S.dan L.K.Dean.2004.Location of Health Care Facilities. Chapter3 in Handbook of OR/MS in Health Care:A Handbook of Methods snd Application,F.Sainfort,M,Brandeau and W.Pierskalla,editors,Kluwer,pp.43-76.

[10] Hordijk,W.1994.Dynamics Emergent Computation and Evolution in Cellular Automata,Erasmus University Rotterdam,Rotterdam.

[11] Jenks, M.,et al.1996.The Compact City: A Sustainable Urban Form, Oxford Brookes University, Oxford, UK. Jayadinata,T,J. 1999. Tata Guna Tanah Perencanaan Pedesaan Perkotaan \& Wilayah, ITB

[12] Keputusan Kepala Dinas Pendidikan KotaBandung No:422.1/1209-Sekrt/2010 tentang Petunjuk Teknis Penerimaan Peserta Didik pada Taman Kanak-kanak,Raudhathul Athfal, Sekolah dan Madrasah Tahun Pelajaran 2010/1011 di Kota Bandung.

[13] Keputusan Menteri Pendidikan Nasional No,0424/U/1993 tanggal 1 Desember 1993 tentang Pembakuan Tipe Sekolah Dasar.

[14] Kecamatan Rancasari (2018), Data Kependudukan Kecamatan Rancasari tahun 2008 dan 2009, data dikumpulkan berdasarkan survei yang dilakukan oleh penulis di empat kelurahan yang ada di kecamatan Rancasari.

[15] Zito,G, dan Donato,S.2006. Dynamical Load Balancing in Cellular Automata Models, Department of Mathematics, University of Calabria, Via Pietro Bucci, Italy.

[16] Gopalakrishnan,G.2002.Computation Engineering:Applied Automata Theory and Logic,

Page $\mid 50$ 
draft version,State University of New York,Stony Brook.

[17] Miranda dan Monteiro.1999. Fuzzy Inference Applied to Spatial , and Forecasting. IEEE Power Tech Conference, Budapest, Hungary. Mitchell,M.1998.Computation in Cellular Automata:A selected Review,working Paper Santa Fe Institute.

[18] Peraturan Menteri Pendidikan Nasional No.24 tahun 2007 tentang Standar sarana dan prasarana untuk Sekolah Dasar/Madrasah Ibtidaiyah (SD/MI),Sekolah Menengah Pertama/Madrasah Tsanawiyah(SMP/MTS), dan Sekolah Menengah Atas/Madrasah Aliyah (SMA/MA).

[19] Peraturan Pemerintah Republik Indonesia No.47 tahun 2008 tentang Wajib Belajar.

[20] Peraturan Menteri Dalam Negeri No.1 tahun 1987 tentang Penyerahan Prasarana Lingkungan,Utilitas Umum dan Fasilitas Sosial Perumahan kepada Pemerintah Daerah.

[21] Segura,D.2005. Principles of Supply Chain Management: A Balanced Approach.Thomson Business and Professional Publishing.

[22] Syarif,A.,Gen,M.2003.Hybridized Parallel Genetic Algorithm for facility location
problem.Makalah penelitian Ilmu computer.cTarigan,R.2006.Perencanaan

Pembangunan Wilayah.Bumi Aksara. ISBN : 979-526-908-9.

[23] Tompkins,W.,Tanchoco,B.2003.Facilities Planning.Third Edition.Wiley International Edition.

[24] Turner,W.,Mize,J.,Case,K dan Nazemetz,J.1993.Introduction To Industrial and System Engineering.Prentice Hall International Series.

[25] Undang-undang Republik Indonesia No.20 Tahun 2003 tentang sistem pendidikan nasional.

[26] Marianov,V1.,Serra,1.2002.FacilityLocation: Aplication and Theory. Spriger-Verlag, ISBN 3540-42172-6.

[27] Von Neuman,J.1966. Theory of Self reproducing Cellular Automata.University of Illinois Press, Urbana.

[28] Wolfram, S. 2002. A New Kind of Science, Wolfram Media, Inc, Canada. Zomaya, A.Y dan Subrata, R.2003. Evolving Cellular Automata for Location Management in Mobile Computing Networks.IEEE transactions on parallel and distributed system, Vol 14,No.1. 